\title{
Recanalisation of coronary chronic total occlusion by retrograde approach: the first experience in Poland
}

\author{
Leszek Bryniarski ${ }^{1}$, Sławomir Surowiec ${ }^{1}$, Łukasz Klima ${ }^{1}$, Michał Terlecki ${ }^{1}$, Piotr Jankowski ${ }^{1}$, Marek Rajzer ${ }^{1}$, \\ Piotr Kusak ${ }^{1}$, Tadeusz Królikowski ${ }^{1}$, Adam Curyło ${ }^{1}$, Krzysztof Żmudka ${ }^{2}$, Dariusz Dudek ${ }^{3}$, Danuta Czarnecka ${ }^{1}$ \\ $11^{\text {st }}$ Department of Cardiology, Interventional Electrocardiology, and Arterial Hypertension, Jagiellonian University, Medical College, \\ University Hospital, Krakow, Poland \\ 2Department of Interventional Cardiology, John Paul II Hospital, Jagiellonian University, Medical College, Krakow, Poland \\ ${ }^{3} 2^{\text {nd }}$ Department of Cardiology and Cardiovascular Interventions, Jagiellonian University, Medical College, \\ University Hospital, Krakow, Poland
}

\section{A bstract}

Background: The effectiveness of revascularisation procedures of coronary chronic total occlusion (CTO) has been improved by the introduction of retrograde approach.

Aim: This study compared the outcomes of CTO revascularisation in a single centre in Krakow, Poland using antegrade and retrograde approach.

Methods: From January 2011 to September 2013, 150 patients underwent 159 procedures for percutaneous revascularisation of CTO of 153 vessels. Of the 159 procedures, 124 (78\%) were performed using an antegrade approach and 35 (22\%) using a retrograde approach.

Results: All patients were symptomatic, with mean CCS class $(2.3 \pm 0.6$ vs. $2.1 \pm 0.7, p=0.9)$, mean age $(59.2 \pm 8.3$ vs. $62.6 \pm 9.9$ years, $p=0.067)$, and mean number of males $(81.3 \%$ vs. $81.8 \%, p=0.9)$ similar in the retrograde and antegrade groups, respectively. Most patients in both groups had ejection fraction (EF) $\geq 50 \%(84.4 \%$ vs. $74.4 \%$, respectively). Occlusions assessed according to the J-CTO score showed that $82.9 \%$ and $56.4 \%$, respectively, were rated as difficult or very difficult $(p<0.01$ ). Overall procedural success rate was $88.2 \%, 87.9 \%$ in the antegrade, and $74.3 \%$ in the retrograde group. Complication rates were low and similar in two groups. However, the retrograde approach was associated with a longer mean fluoroscopy time $(47.8 \pm 19.6$ vs. $19.3 \pm 10.0 \mathrm{~min}, \mathrm{p}<0.00001)$ and higher volume of contrast fluid $(494.6 \pm 142.4$ vs. $291.9 \pm 118.1 \mathrm{~mL}, \mathrm{p}<0.00001)$.

Conclusions: Using novel equipment with adequate experience allowed high rates of successful revascularisation. The retrograde technique for CTO revascularisation showed good overall success and was safe.

Key words: percutaneous coronary intervention, chronic total occlusions, retrograde approach

Kardiol Pol 2015; 73, 3: 167-176

\section{INTRODUCTION}

Revascularisation procedures for coronary chronic total occlusions (CTO) are very difficult. The procedural complexity of CTO angioplasty and the lack of familiarity with new equipment and techniques often lead to treatment failure. Opening a chronic occlusion in an area supplied by a closed artery can be benefitial for patients with confirmed myocardial viability.
Opening an occlusion can lead to angina relief, reduce the severity of arrhythmias, improve left ventricular contractility, and reduce patient mortality $[1,2]$.

Revascularisation using a retrograde approach is a relatively new strategy for the treatment of chronic occlusions [3]. This method is based on the assumption that crossing the occlusion with a distal guidewire is easier because of its lower 
hardness than the proximal cap [4]. The rate of effectiveness of the classic antegrade approach for CTO in Poland in 2009-2012, according to Association of Percutaneous Cardiovascular Interventions of the Polish Cardiac Society database, was $63.6 \%$, similar to previous findings [5]. Recanalisation using the retrograde approach is rarely performed in Poland. We present our initial experience using the retrograde approach for recanalisation of coronary CTO.

\section{METHODS}

\section{Study design}

The patient cohort consisted of 150 patients who underwent 159 revascularisation procedures on 153 vessels from January 2011 to September 2013 in the Haemodynamics Laboratory of Cardiology Institute, Jagiellonian University, all performed by an interventional cardiologist specialising in revascularisation of CTO. Of these 159 procedures, 35 (22.0\%) were performed by retrograde and $124(78.0 \%)$ by antegrade recanalisation techniques. Retrograde procedures were performed after earlier unsuccessful antegrade recanalisation or in patients with unfavourable morphology likely to have a low chance of success using the antegrade approach. Procedures performed under the supervision or in association with foreign experts were excluded.

\section{Definitions}

CTO was defined as a $>$ three-month interruption in the continuity of the artery lumen with a flow of Thrombolysis in Myocardial Infarction (TIMI) 0 [6]. Occlusions were determined according to the EuroCTO Club definition as sure (i.e. the presence of occlusion in the previous angiogram), probable (clinically confirmed, with documented myocardial infarction in area of closed artery for $>$ three months and no other changes), and possible (undefined, including CTO with a flow of TIMI 0, angiographic image suggesting CTO and stable clinical symptoms in the past three months, or the presence of silent ischaemia; in patients with acute coronary syndrome culprit artery other than closed) [6].

A successful procedure was defined as artery recanalisation with a TIMI 3 flow and residual stenosis not exceeding 30\%.

In-hospital major adverse cardiovascular events were defined as death, emergency repeat revascularisation at the previously opened artery, emergency coronary artery bypass grafting (CABG), or stroke. Complications of general and specific CTO included perforation, damage to the proximal part of the artery, dissection or a blood clot in a contralateral vessel. Serum creatinine concentration was measured in all patients at baseline and $24 \mathrm{~h}$ after the procedure to assess the incidence of contrast-induced nephropathy. Despite the changed definition of periprocedural myocardial infarction (type 4) in 2012 [7], the results of this study were standardised by defining a myocardial infarct as a three-fold increase in markers of myocardial necrosis.

\section{Treatment techniques}

Angiographic images were analysed in detail, with special attention paid to the morphology of the occlusion and the collateral circulation, with the intervention strategy based on this analysis. No recanalisation procedures were performed "ad hoc" immediately after diagnostic coronary angiography.

All patients were treated with dual antiplatelet therapy, consisting of aspirin and clopidogrel or prasugrel. Activated clotting time (ACT) was measured every 30 min during the operation, and unfractionated heparin was administered to maintain ACT at more than $250 \mathrm{~s}$ and $300 \mathrm{~s}$ for the antegrade and retrograde approaches, respectively. Treatments were performed via femoral access using a $7 \mathrm{~F}$ or $8 \mathrm{~F}$ sheath, usually $45 \mathrm{~cm}$ long, armed, for maximum support. Guiding catheters were size $7 \mathrm{~F}$ or $8 \mathrm{~F}$. The left coronary artery was intubated with a extra back-up (EBU) or left Judkins catheter, the right coronary artery with an Amplatz catheter or with a right Judkins catheter, with most catheters having side holes. Most guiding catheters were $90 \mathrm{~cm}$ long, allowing the contralateral transfer of a long guidewire, especially when using epicardial collaterals or in taller patients.

The retrograde percutaneous coronary intervention $(\mathrm{PCl})$ procedure was initiated by introducing a hydrophilic guidewire using a microcatheter $(n=29,82.9 \%)$ or an over-the-wire balloon. When the angles of the perforators or epicardial branches were acute, a standard soft guidewire with a properly formed tip was introduced through the microcatheter. The soft guidewire was subsequently exchanged for a guidewire crossing the collaterals. The connection to the target vessel was confirmed by selective administration of contrast through the microcatheter. Septal or epicardial collaterals were used, depending on the morphology of the collateral vessels. If visualisation of connections via perforators was poor we used the septal surfing technique [8]. After the guidewire was transferred through the collaterals, the microcatheter was brought as close as possible to the distal site of occlusion. If the hydrophilic wire could not pass through the occlusions, it was replaced by a stiffer wire (Miracle or Confianza; Asahi Intecc, Japan).

Techniques used for revascularisation included retrograde wire crossing, in which the vessel was opened by backwards insertion of the wire [9]; touching wire, in which guidewires were inserted through both sides of the occlusion; and controlled antegrade and retrograde sub-intimal tracking (CART) and reverse CART, in which the antegrade wire was introduced into the occlusion, and by expanding the antegrade balloon in subintimal space it was possible to introduce there the retrograde wire $[10,11]$.

After introducing the guidewire and microcatheter from the contralateral artery into the proximal part of the closed vessel and then into the guiding catheter, the guidewire was changed to RG3 for externalisation (Intecc Asahi, Japan) and transfer through the guiding catheter to the opposite side of 


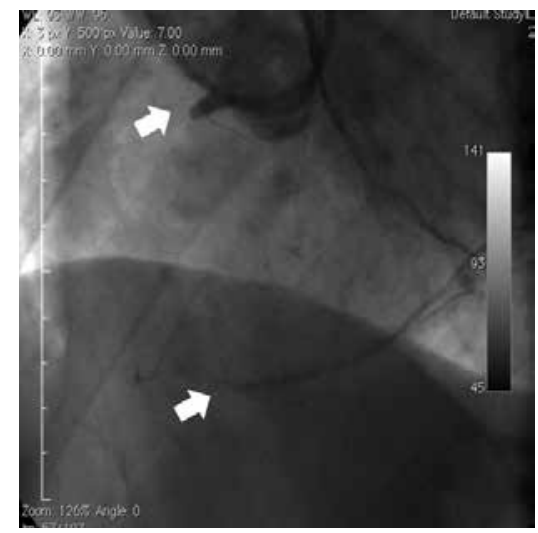

Figure 1. Long occlusion of the right coronary artery. Arrows show the distal and proximal ends of the occlusion

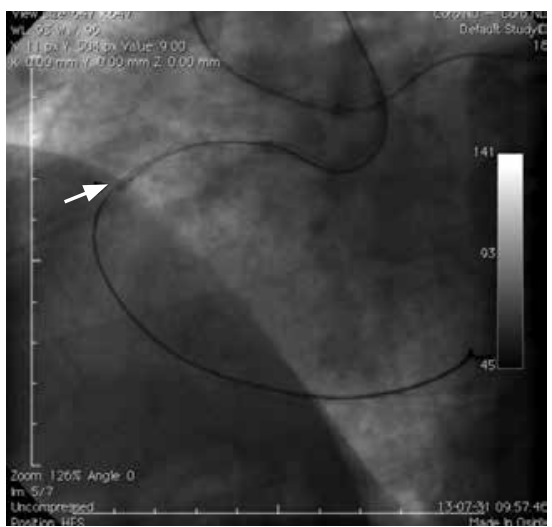

Figure 4. Reverse-controlled antegrade and retrograde sub-intimal tracking technique, in which a reverse guidewire is introduced to the occlusion. The arrow shows an inflated balloon placed on the guidewire that was inserted from the front

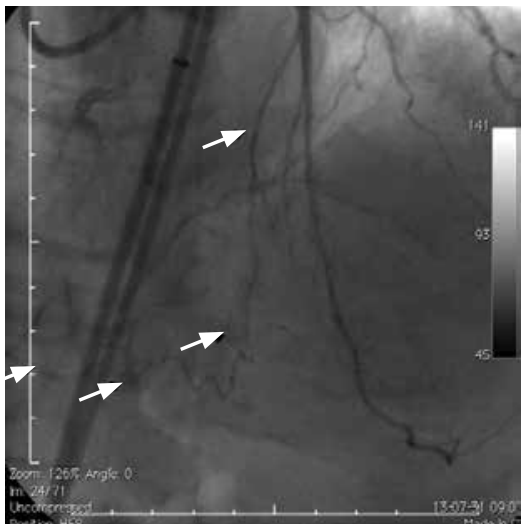

Figure 2. Epicardial collaterals connecting the left (circumflex artery) and right coronary arteries (arrows)

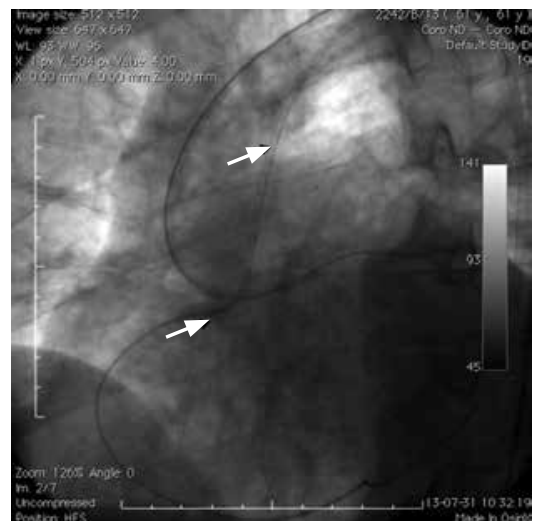

Figure 5. Inserting the guidewires (arrows) from the left coronary artery to the catheter introduced into the right coronary artery

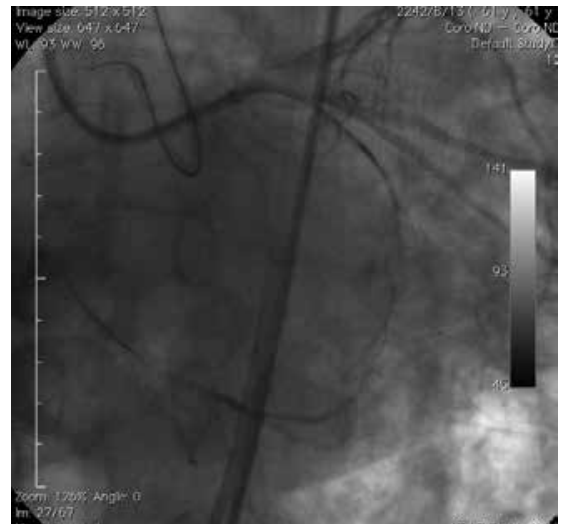

Figure 3. Guidewire inserted through epicardial collaterals into the right coronary artery

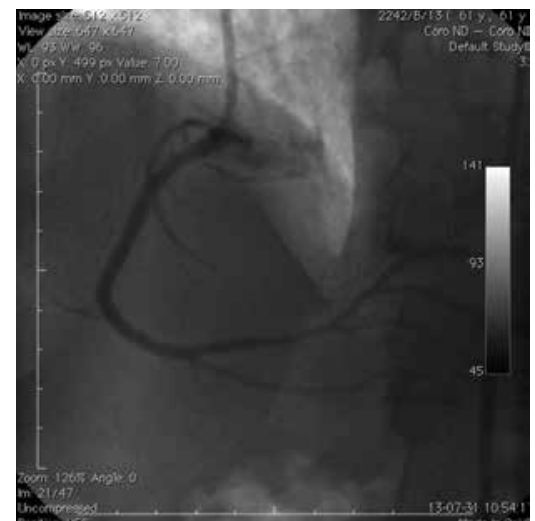

Figure 6. Optimal result after drug eluting stents implantation

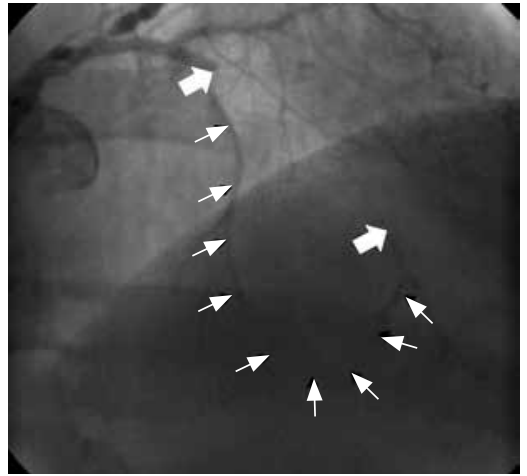

Figure 7. Long occlusion of the left anterior descending artery. The arrows indicate the connection between the first large septal branch and the distal septal branch (ipsilateral collateral circulation)

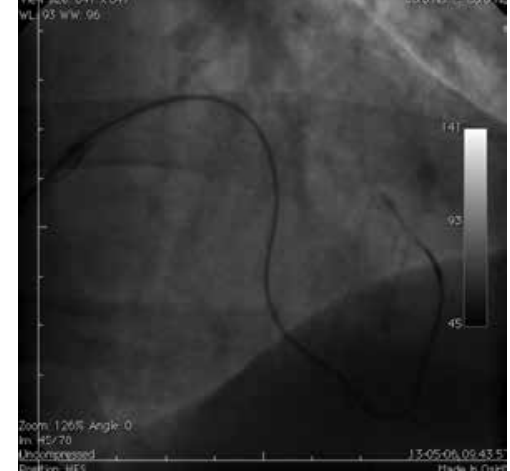

Figure 8. Selective injection of contrast medium through a Corsair microcatheter, showing its correct position, as well as a critical stenosis of the left anterior descendens directly behind the tip of the catheter

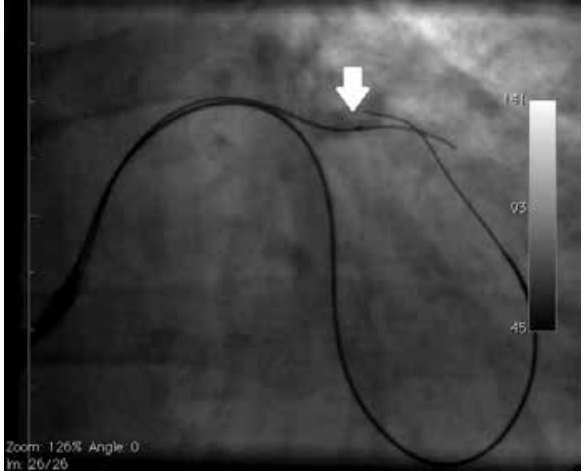

Figure 9. Reverse-controlled antegrade and retrograde sub-intimal tracking technique. The arrow indicates the inflated balloon inserted on the guidewire from the front 


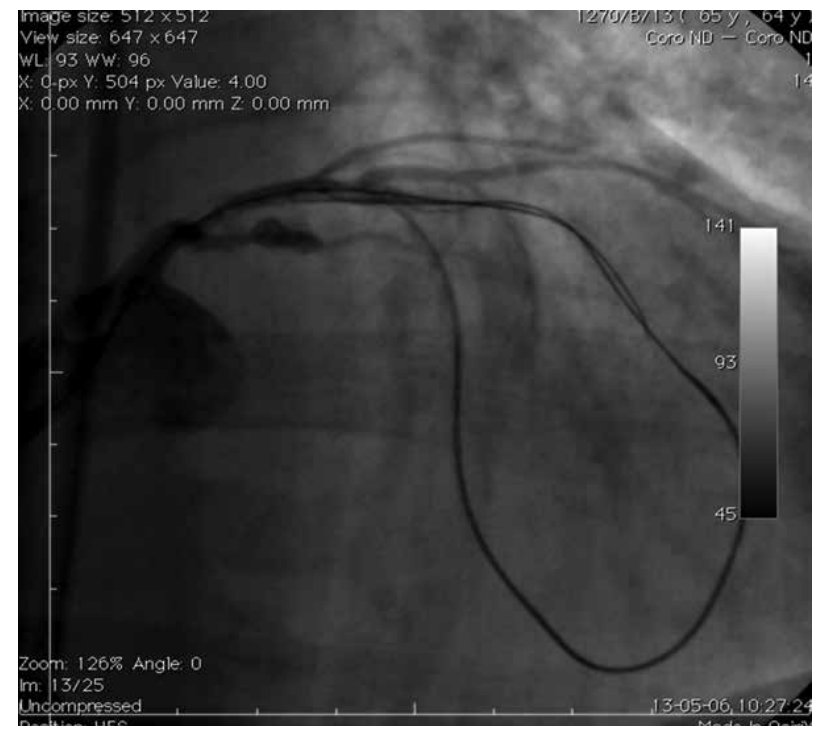

Figure 10. Conducting the guidewire backwards into the proximal left anterior descending artery. The guidewire inserted from the front is also visible

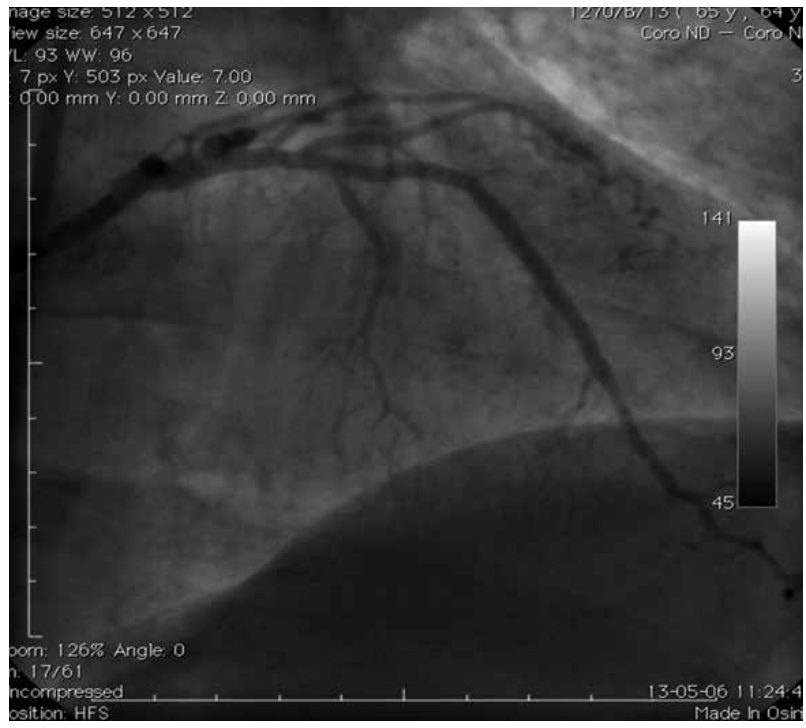

Figure 11. Optimal result after drug eluting stents implantation

Table 1. Demographic and clinical characteristics of the retrograde and antegrade groups

\begin{tabular}{lccc} 
& Retrograde group (32 patients) & Antegrade group (121 patients) & P \\
\hline Hypertension & $25(78.1 \%)$ & $106(87.6 \%)$ & 0.2 \\
Hypercholesterolaemia & $31(96.9 \%)$ & $119(98.3 \%)$ & 0.6 \\
Diabetes & $9(28.1 \%)$ & $40(33.6 \%)$ & 0.6 \\
Smoking: & & & \\
$\quad$ Current smoker & $10(31.2 \%)$ & $24(19.8 \%)$ & 0.5 \\
Previous smoker & $15(46.9 \%)$ & $60(49.6 \%)$ & 0.3 \\
Previous myocardial infarction & $16(50.0 \%)$ & $56(46.3 \%)$ & 0.4 \\
Previous PCI & $29(90.6 \%)$ & $73(60.3 \%)$ & $<0.002$ \\
Previous CABG & $1(3.1 \%)$ & $4(3.3 \%)$ & 0.9 \\
LVEF $>50 \%$ & $27(84.4 \%)$ & $90(74.4 \%)$ & 0.5 \\
LVEF $<50 \%$ & $4(12.5 \%)$ & $23(19.0)$ & 0.6 \\
LVEF $<35 \%$ & $1(3.1 \%)$ & $8(6.6 \%)$ & 0.5 \\
Previous attempted revascularisation & $20(62.5 \%)$ & $44(36.3 \%)$ & 0.007 \\
\hline
\end{tabular}

CABG — coronary artery bypass grafting; LVEF — left ventricular ejection fraction; $\mathrm{PCl}$ — percutaneous coronary intervention

the groin. The balloon was inflated and the stent(s), covered with antimitotic drug, were implanted. Examples of procedures are shown in the pictures (Figs. 1-11).

\section{Statistical analysis}

Continuous variables are presented as means \pm standard deviations, and discrete variables as numbers and percentages. Differences were compared using Student's t-test, the Mann-Whitney $U$ test, or the $\chi^{2}$ test, as appropriate. All tests were two-sided, with a $p$ value $<0.05$ considered statistically significant.

\section{RESULTS}

The cohort of 150 patients underwent $159 \mathrm{PCl}$ on 153 vessels, including repeat procedures. Three patients, who underwent unsuccessful recanalisation by the antegrade approach followed by attempt to open using the retrograde approach, were included in both groups (Table 1).

The average age of patients in the retrograde- and antegrade-approach groups were $59.2 \pm 8.3$ years and $62.6 \pm 9.9$ years, respectively $(p=0.3)$. Of these two groups, $81.3 \%$ and $81.8 \%$, respectively, were male $(p=0.9)$. The incidence of major risk factors for coronary heart disease, 
Table 2. Angiographic assessment of occlusion in the retrograde and antegrade groups

\begin{tabular}{|c|c|c|c|}
\hline & $\begin{array}{c}\text { Retrograde group } \\
\text { (35 procedures) }\end{array}$ & $\begin{array}{l}\text { Antegrade group } \\
\text { (124 procedures) }\end{array}$ & $\mathbf{P}$ \\
\hline \multicolumn{4}{|l|}{ Lesion site: } \\
\hline LAD & $12(34.2 \%)$ & $42(33.9 \%)$ & \\
\hline$c x$ & $1(2.9 \%)$ & $29(23.4 \%)$ & 0.01 \\
\hline RCA & $22(62.9 \%)$ & $53(42.7 \%)$ & \\
\hline Number of atherosclerotic arteries & $1-17(48.6 \%)$ & $1-57(45.9 \%)$ & 0.9 \\
\hline \multirow[t]{2}{*}{ (including CTO) } & $2-11(31.4 \%)$ & $2-39(31.5 \%)$ & \\
\hline & $3-7(20 \%)$ & $3-28(22.6 \%)$ & \\
\hline Occlusion morphology: blunt or no stump & $25(71.4 \%)$ & $59(47.6 \%)$ & 0.01 \\
\hline \multicolumn{4}{|l|}{ Calcification: } \\
\hline None & $2(11.8 \%)$ & $23(16.2 \%)$ & \\
\hline Mild & $10(58.8 \%)$ & $81(57.0 \%)$ & 0.5 \\
\hline Moderate and severe & $5(29.4 \%)$ & $38(26.8 \%)$ & \\
\hline Lesion length of CTO [mm] & $30.0 \pm 20.9$ & $23.3 \pm 9.8$ & 0.0007 \\
\hline Duration of CTO [months] & $25.1 \pm 39.4$ & $14.6 \pm 30.0$ & 0.09 \\
\hline Confirmation of CTO: & & & 0.2 \\
\hline Clinically & $10(28.6 \%)$ & $56(45.2 \%)$ & \\
\hline Angiographically & $23(65.7 \%)$ & $59(47.6 \%)$ & \\
\hline Uncertain & $2(5.7 \%)$ & $9(7.3 \%)$ & \\
\hline Fluoroscopy time [min] & $47.8 \pm 19.6$ & $19.3 \pm 10.0$ & $<0.00001$ \\
\hline Amount of contrast [mL] & $494.6 \pm 142.4$ & $291.9 \pm 118.1$ & $<0.00001$ \\
\hline Radiation dose [Gy] & $3.7 \pm 1.7$ & $2.1 \pm 1.2$ & $<0.007$ \\
\hline Procedure time [min] & $97.0 \pm 20.2$ & $57.3 \pm 19.9$ & $<0.00001$ \\
\hline \multirow[t]{3}{*}{ J-CTO score } & $1-0(0.0 \%)$ & $1-21(16.9 \%)$ & 0.01 \\
\hline & $2-6(17.1 \%)$ & $2-32(25.8 \%)$ & \\
\hline & $\geq 3-29(82.9 \%)$ & $\geq 3-60(56.4 \%)$ & \\
\hline
\end{tabular}

CTO — chronic total occlusion; LAD — left anterior descending artery; LX — circumflex artery; RCA — right coronary artery

including hypertension, hypercholesterolaemia, diabetes, and smoking was similar in the two groups (Table 1).

The rates of previously performed percutaneous coronary revascularisation differed significantly in the retrograde and antegrade groups $(p=0.007)$. Left ventricular ejection fraction, assessed by transthoracic echocardiography, and the number of vessels with coronary stenosis were similar in the two groups, as was the severity of angina symptoms, as assessed by Canadian Cardiovascular Society (CCS) class $(2.3 \pm 0.6$ vs. $2.1 \pm 0.7, \mathrm{p}=0.9)$.

Table 2 shows the angiographic assessment of arteries. The most frequently treated artery in the retrograde and antegrade groups was the right coronary artery, followed by the anterior descending artery and the circumflex artery. More than half of the patients in both groups $(p=0.8)$ had atherosclerotic changes in at least two vessels. There was no significant difference in angiographically assessed arterial calcification between groups. Duration of chronic occlusion tended to be longer in the retrograde group $(p=0.09)$. Lesions were significantly longer in the retrograde group $(30.0 \pm 20.9$ vs. $23.3 \pm 9.8 \mathrm{~mm}$, $\mathrm{p}<0.05$ ), and the morphology less favourable, with no stump or a blunt stump more frequently observed in the retrograde group $(71.4 \%$ vs. $47.6 \%, p<0.001)$ (Table 2 ).

Changes were quantitated using the J-CTO score [12], which takes into account vessel stump morphology (blunt, tapered, or absent), the presence of calcifications, bending $>45^{\circ}$ within the CTO segment, length of occlusion $\geq 20 \mathrm{~mm}$, and repeat recanalisation. According to this score, $82.9 \%$ of vessels in the retrograde group and $56.4 \%$ of vessels in the antegrade group were classified as very difficult ( $\geq 3$ points; $p=0.01$ ).

A Corsair (Asahi Intecc, Japan) or Quickcross (Spectranetics, USA) microcatheter, which are now an integral part of $\mathrm{PCl}$ using a retrograde approach, were used in 29 of the 35 retrograde procedures (82.9\%). In 23 (65.7\%) procedures, a guidewire was passed through the septal collaterals, whereas in nine $(25.7 \%)$ it was passed through epicardial connections. During five (14.3\%) procedures, attempts were made to 
Table 3. Devices used for retrograde and antegrade techniques

\begin{tabular}{lccc} 
& $\begin{array}{c}\text { Retrograde group } \\
\text { (35 procedures) }\end{array}$ & $\begin{array}{c}\text { Antegrade group } \\
\text { (124 procedures) }\end{array}$ & $<0.0000001$ \\
\hline Mean number of wires & $3.2 \pm 1.2$ & $1.7 \pm 0.8$ & 0.2 \\
Intravascular ultrasound & $2(5.7 \%)$ & $2(1.6 \%)$ & $<0.0000001$ \\
Corsair or Quickcross (1 case) & $29(82.9 \%)$ & $2(1.6 \%)$ & $<0.0002$ \\
Externalisation (\% of successful procedures) & $13(50.0 \%)$ & $54(43.6 \%)$ & \\
Contralateral injections & $28(80 \%)$ & & 0.4 \\
Touching wire (\% of successful procedures) & $8 / 23(34.8 \%)$ & & 0.1 \\
Reverse CART (\% of successful procedures) & $5 / 23(21.7 \%)$ & $3(2.4 \%)$ & $1.1 \pm 0.8$ \\
CART (\% of successful procedures) & $1 / 23(4.3 \%)$ & \\
Wire cross (\% of successful procedures) & $9 / 23(39.1 \%)$ & $0(0 \%)$ & \\
Tornus & $1.3 \pm 1.1$ & & \\
Mean number of stents & & & \\
\hline
\end{tabular}

CART — controlled antegrade and retrograde sub-intimal tracking

reach through the ipsilateral connection by moving backward within a vessel through its branches; and in two (6.7\%) procedures, intracoronary ultrasound was used to locate the position of the guidewire and find a way out of the subintimal space.

An important element of the $\mathrm{PCl}$ procedure is the proper selection of guidewires. The number of guidewires used for CTO is usually greater than that used for critically narrowed arteries. The mean number of wires was significantly greater in the retrograde than in the antegrade group $(3.2 \pm 1.2$ vs. $1.7 \pm 0.8, p<0.0000001)$. All retrograde procedures required at least three wires, with two procedures requiring eight wires.

The first guidewires for the retrograde approach were from the Fielder (Asahi Intecc, Japan; $\mathrm{n}=17,48.6 \%$ ) and Sion (Asahi Intecc; $\mathrm{n}=13,37.1 \%$ ) groups, whereas the first guidewires for the antegrade approach were from the Fielder $(\mathrm{n}=76,61.3 \%$ ) and Whisper (Abbott Vascular, USA; $\mathrm{n}=14$, $11.3 \%$ ) groups. Table 3 shows the type and number of devices used for each technique.

The success rate for the retrograde approach was $65.7 \%$ (23/35). The antegrade approach was also successful in three of five cases in whom the retrograde approach was unsuccessful during the same procedure, making the overall effectiveness in the retrograde group $74.3 \%(26 / 35)$.

In the antegrade group, 109 of $124(87.9 \%)$ arteries were opened successfully. Thus, of 153 arteries, 135 (88.2\%) were opened successfully.

The guidewires that passed through the occlusion were Confianza Pro 12 (15/26, 57.6\%), Sion (6/26, 23.1\%), and Fielder XT $(5 / 26,19.2 \%)$ in the retrograde group and Fielder XT (43/109, 39.4\%), Confianza Pro 12 (27/109, 24.8\%), and Miracle $(26 / 109,23.9 \%)$ in the antegrade group. Miracle guidewires were $12 \mathrm{~g}$ for eight occlusions, $6 \mathrm{~g}$ for three, and $3 \mathrm{~g}$ for 15 .
Drug-eluting stents (DES) were implanted to the vessels that underwent successful recanalisation. The mean number of stents $(1.3 \pm 1.1$ vs. $1.1 \pm 0.8, p=0.7)$ and mean stent diameter $(3.0 \pm 0.3 \mathrm{~mm}$ vs. $2.9 \pm 0.4 \mathrm{~mm}, \mathrm{p}=0.8)$ were similar in the retrograde and antegrade groups, but mean stent length was significantly longer in the retrograde group (49.6 \pm 26.5 vs. $28.6 \pm 20.9 \mathrm{~mm}, \mathrm{p}<0.0001)$. Stents implanted frequently in the retrograde and antegrade groups included Endeavor (Medtronic, USA) (7/26 [26.9\%] vs. 33/109 [30.3\%]), Promus (Boston Scientific, USA) (6/26 [23.1\%] vs. 26/109 [23.8\%]), and Xience (Abbott Vascular, USA) (7/26 [26.9\%] vs. 19/109 [17.4\%]).

The reasons for the ineffectiveness of the retrograde approach in the 12 patients were not crossing collaterals $(n=9)$ and not crossing the occlusion from the proximal or distal end.

After successful recanalisation, $22(84.6 \%)$ patients in the retrograde group and 93 (85.3\%) in the antegrade reported a reduction of angina symptoms while in hospital.

No serious complications of $\mathrm{PCl}$ using the retrograde approach were reported. None of the patients required target vessel revascularisation, CABG, or urgent $\mathrm{PCl}$ after the procedure.

None of the patients in the retrograde group experienced any in-hospital major adverse cardiac events. In contrast, two patients in the antegrade group experienced in-hospital major adverse cardiovascular events. One showed an asymptomatic increase in markers of myocardium necrosis, meeting the criteria for myocardial infarction. The other patient reported transient blurred vision after the procedure, which was judged by a neurologist as a stroke. However, no changes were found in computed tomography, and this symptom resolved completely before the patient was discharged (Table 4).

One patient in the retrograde group experienced a large haematoma at the puncture site of the left femoral artery, 
Table 4. In-hospital major adverse cardiovascular events and complications

\begin{tabular}{|lccc|} 
& $\begin{array}{c}\text { Retrograde group } \\
\text { (35 procedures) }\end{array}$ & $\begin{array}{c}\text { Antegrade group } \\
\text { (124 procedures) }\end{array}$ & P \\
\hline Death & $0(0 \%)$ & $0(0 \%)$ & 0.6 \\
Myocardial infarction & $0(0 \%)$ & $1(0.8 \%)$ & 0.6 \\
Stroke & $0(0 \%)$ & $1(0.8 \%)$ & 0.3 \\
Artery perforation (mild) & $0(0 \%)$ & $4(3.2 \%)$ & 0.3 \\
Artery dissection & $1(2.9 \%)$ & $1(0.81 \%)$ & 0.3 \\
Vascular complications & $1(2.9 \%)$ & $1(0.81 \%)$ & \\
\hline
\end{tabular}

coating the abdomen, the inner part of the thigh, and the groin. The patient did not require blood transfusions, but, because of the inefficiency of medical management and the risk of skin necrosis, the haematoma was evacuated surgically after ten days. In the antegrade group, one patient had an arteriovenous fistula, which was treated conservatively.

One patient in the retrograde group with an occluded right coronary artery underwent dissection of the proximal left anterior descending artery (LAD), taking the distal part of the left main (LM) artery. This procedure required stenting of the LM artery and proximal LAD. Good result of LM angioplasty was confirmed four months later, and the right coronary artery was opened effectively using the retrograde technique. One patient in the antegrade group underwent dissection of the proximal part of the right coronary artery caused by the leading Amplatz left catheter and was treated with stent implantation.

\section{DISCUSSION}

Despite requiring considerable experience, recanalisation of coronary CTO using the retrograde approach has been shown to be effective and safe [13] and is recommended by the European Consensus CTO Club as a second approach after failure of recanalisation by the antegrade approach or when the predicted effectiveness of the antegrade method is below $50 \%$ [8]. The retrograde method is based on the assumption that the distal cap of the occlusion is softer than the proximal part, making the former easier to cross with the guidewire [4]. The relative softness of the distal part is thought to be due to the perfusion pressure of the collateral circulation being lower than the system pressure, making it possible to pass through the occlusion without using stiffer wires. This assumption does not apply to patients after CABG, because the system pressure is transferred through the implanted bypass to the coronary arteries. Moreover, higher system pressure may be produced during previous attempts at antegrade dissection, preventing re-access from the front. In addition, the site of occlusion may be difficult to detect [14].

Among the patients examined in the present work, the overall effectiveness of retrograde CTO was $74.3 \%$. Using the retrograde technique only, $65.7 \%$ of coronary arteries were opened. The overall success rate of the retrograde and antegrade techniques was $88.2 \%$; similar to results obtained at highly experienced interventional cardiology centres in Europe [15], the United States of America [16], and Japan [17]. Our rate of effectiveness of the retrograde method was slightly lower than in several previous reports [9] but was comparable to the $71.2 \%$ recently reported in a Japanese study [18]. The retrograde method was recently introduced to our centre, with the results highly dependent on the skill and experience of the operators [18].

Guidewires for $\mathrm{PCI}$ CTO require adequate and delicate manipulation, especially when passing through collaterals. The ability to select the appropriate collaterals is crucial in avoiding tortuous and poorly visible connections [9]. In addition, the use of septal collaterals, selected in $65.7 \%$ of revascularisations using the retrograde approach, had an advantage over use of the epicardial arteries, because the interventricular septum provides protection against damage to the vessel wall, as well as against serious bleeding and tamponade. Failure of retrograde techniques primarily due to the choice of an incorrect connecting branch, one that is absent, or one that has an unfavourable morphology. In our study the most frequent cause of failure was the inability to pass through collaterals, observed in $26.8 \%$ of these procedures [19].

Knowledge of the techniques [20] and equipment used in the revascularisation of coronary CTO and proper planning of treatment strategies are essential for the effectiveness of these treatments. The types of guidewires used in this study, both in the antegrade and retrograde groups, were consistent with data from the Euro CTO Club, although slight differences may be due to the preferences of individual operators. Knowledge of the characteristics of these special guidewires for $\mathrm{PCl}$ of chronic occlusion and their adaptation to the morphology of the occlusion is required for their proper manipulation [21].

In some patients there is a need to change the planned technique to another during the procedure. The most commonly used retrograde techniques in our centre were a backward transfer of the guidewire (pure retrograde method) (39.1\%) and touching wire $(34.8 \%)$, in which the distal guidewire serves as a reference point for the proximal guidewire. More than $25 \%$ of these procedures were performed using the CART or reverse CART method. The frequency of use of 
individual revascularisation techniques has been found to vary considerably among European centres [9]. This may be due to the speed at which operators learn and incorporate these techniques in their clinical practice. In Japan, the CART technique $(40 \%)$ and wire crossing (25\%) are the methods utilised most frequently with the retrograde approach [22].

Modern hydrophilic guidewires (Fielder, Sion) as well as Corsair microcatheters have been reported to enhance the effectiveness of the retrograde technique. Use of microcatheters has enabled guidewires to pass more frequently through collaterals, thus improving success rates without increasing complications associated with injury to collaterals [22, 23]. Microcatheters, mainly Corsair microcatheters, were used in more than $82 \%$ of our patients.

Occlusions in the retrograde group were regarded as having a low chance of success, or were reanalysed after a previous unsuccessful attempt to open them using the classical method. A comparison of the J-CTO scores [12] in both groups showed that a significantly greater percentage of patients in the retrograde than in the antegrade group were classified as very difficult ( $82.9 \%$ vs. $56.4 \%$ ). J-CTO score is an independent predictor of treatment efficacy, as well as being an easy-to-use parameter when making decisions about revascularisation in everyday clinical practice [24].

We performed revascularisation procedures on patients with severe angina of above average CCS class II, who had received optimal pharmacological treatment, often after unsuccessful $\mathrm{PCl}$, with most having preserved left ventricular function (ejection fraction $>50 \%$ in $82.9 \%$ of the retrograde and $74.2 \%$ of the antegrade group). Thus, it was not surprising that up to $85 \%$ of patients who underwent successful recanalisation reported symptom improvement while in hospital. Recanalisation of coronary CTO by both the antegrade and retrograde approaches was safe. A meta-analysis involving more than 18,000 patients from 65 studies showed a low risk of complications, including major complications, such as death, myocardial infarction, and tamponade. No deaths were reported following 886 procedures using the retrograde approach, and the rates of emergency CABG and tamponade were low [13].

The incidence of complications in our study was very low. One patient in the antegrade group had a myocardial infarction, one had a stroke, and one had a mild coronary artery perforation. In comparison, none of the patients in the retrograde group experienced a serious coronary event, such as myocardial infarction, cardiac tamponade, or acute ischaemia, although one patient experienced bleeding from the puncture site of the femoral artery. Less aggressive conduct during the procedure may increase its safety, but may also reduce its efficacy. Although the ineffectiveness of $\mathrm{PCl}$ treatment was shown to be correlated with an increased rate of complications, this did not result in an increase in complexity among our patients.
The average duration of the retrograde procedure was significantly longer than that of the antegrade method $(97.0 \pm 20.2$ vs. $57.3 \pm 19.9$ minutes). Despite the larger volume of contrast used for the retrograde method $(494.6 \pm 142.4$ vs. $291.9 \pm 118.1 \mathrm{~mL})$, no patient experienced contrast-induced nephropathy. Finally, care was taken to minimise the radiation dose during retrograde procedures, resulting in an average radiation dose in our patients of about 3.7 Gy.

It has been recommended that retrograde techniques should be performed by operators who recanalysed $>300$ occlusions and who perform more than 50 of these procedures per year [8]. Thus, this technique should be performed only at selected, experienced centres, especially in patients with J-CTO scores $\geq 2$, thus reducing the risks associated with the difficulties of the procedure and its possible complications. With participation in workshops and courses, and by inviting world experts, increases are being seen in the effectiveness of treatments, and new techniques are being implemented. Close collaboration with other catheter laboratories allows the classification of patients correctly to $\mathrm{PCl}$ of CTO. We hope that in the near future the National Health Fund will extract these procedures from the catalogue of services requiring major financial expenditure.

\section{CONCLUSIONS}

Use of the retrograde approach for revascularisation of coronary CTO may result in a high success rate. This technique improved the effectiveness of treatment, and it was safe.

\section{Acknowledgements}

We would like to thank all of our colleagues who participated in this project, without whose help in recruiting patients with the proper characteristics this work would not have been possible.

\section{Conflict of interest: none declared}

\section{References}

1. Suero JA, Marso SP, Jones PG et al. Procedural outcomes and long-term survival among patients undergoing percutaneous coronary intervention of a chronic total occlusion in native coronary arteries: a 20-year experience. J Am Coll Cardiol, 2001; 38: 409-414.

2. Stone GW, Reifart NJ, Moussa I et al. Percutaneous recanalization of chronically occluded coronary arteries: a consensus document: part II. Circulation, 2005; 112: 2530-2537.

3. Kahn JK, Hartzler GO. Retrograde coronary angioplasty of isolated arterial segments through saphenous vein bypass grafts. Cathet Cardiovasc Diagn, 1990; 20: 88-93.

4. Fujii K, Ochiai M, Mintz GS et al. Procedural implications of intravascular ultrasound morphologic features of chronic total coronary occlusions. Am J Cardiol, 2006; 97: 1455-1462.

5. Mehran R, Claessen BE, Godino C et al. Long-term outcome of percutaneous coronary intervention for chronic total occlusions. J Am Coll Cardiol Cardiovasc Interv, 2011; 4: 952-961.

6. Di Mario C, Werner GS, Sianos G et al. European perspective in the recanalisation of chronic total occlusions (CTO): consensus document from the EuroCTO Club. EuroIntervention, 2007; 3: 30-43. 
7. Thygesen K, Alpert JS, Jaffe AS et al. Third universal definition of myocardial infarction. Eur Heart J, 2012; 33: 2551-2567.

8. Sianos G, Werner GS, Galassi AR et al. Recanalisation of chronic total coronary occlusions: 2012 consensus document from the EuroCTO club. EuroIntervention, 2012; 8: 139-145.

9. Sianos G, Barlis P, Di Mario C et al. European experience with the retrograde approach for the recanalisation of coronary artery chronic total occlusions. A report on behalf of the EuroCTO club. EuroIntervention, 2008; 4: 84-92.

10. Sumitsuji S, Inoue K, Ochiai M et al. Fundamental wire technique and current standard strategy of percutaneous intervention for chronic total occlusion with histopathological insights. J Am Coll Cardiol Cardiovasc Interv, 2011; 4: 941-951.

11. Garcia S, Abdullah S, Banerjee $S$ et al. Chronic total occlusions: patient selection and overview of advanced techniques. Curr Cardiol Rep, 2013; 15: 334.

12. Morino $\mathrm{Y}, \mathrm{Abe} \mathrm{M}$, Morimoto $\mathrm{T}$ et al. Predicting successful guidewire crossing through chronic total occlusion of native coronary lesions within 30 minutes: the J-CTO (Multicenter CTO Registry in Japan) score as a difficulty grading and time assessment tool. J Am Coll Cardiol Cardiovasc Interv, 2011; 4: 213-221.

13. Patel VG, Brayton KM, Tamayo A et al. Angiographic success and procedural complications in patients undergoing percutaneous coronary chronic total occlusion interventions: a weighted meta-analysis of 18,061 patients from 65 studies. J Am Coll Cardiol Cardiovasc Interv, 2013; 6: 128-136.

14. Saito S. Different strategies of retrograde approach in coronary angioplasty for chronic total occlusion. Catheter Cardiovasc Interv, 2008; 71: 8-19.

15. Galassi AR, Tomasello SD, Reifart N et al. In-hospital outcomes of percutaneous coronary intervention in patients with chronic total occlusion: insights from the ERCTO (European Registry of Chronic Total Occlusion) registry. EuroIntervention, 2011; 7: 472-479.

16. Michael TT, Karmpaliotis D, Brilakis ES et al. Procedural outcomes of revascularization of chronic total occlusion of native coronary arteries (from a multicenter United States registry). Am J Cardiol, 2013; 112: 488-492.

17. Rathore S, Matsuo H, Terashima M et al. Procedural and in-hospital outcomes after percutaneous coronary intervention for chronic total occlusions of coronary arteries 2002 to 2008: impact of novel guidewire techniques. J Am Coll Cardiol Cardiovasc Interv, 2009; 2: 489-497.

18. Tsuchikane E, Yamane M, Mutoh M et al. Japanese multicenter registry evaluating the retrograde approach for chronic coronary total occlusion. Catheter Cardiovasc Interv, 2013; 82: E654-E661.

19. Rathore S, Katoh O, Matsuo $\mathrm{H}$ et al. Retrograde percutaneous recanalization of chronic total occlusion of the coronary arteries: procedural outcomes and predictors of success in contemporary practice. Circ Cardiovasc Interv, 2009; 2: 124-132.

20. Bryniarski L, Kusak P, Surowiec S et al. Dedicated devices and techniques - a cornerstone in recanalization of chronic total occlusions of coronary arteries. Adv Intervent Cardiol, 2014; 10: $213-215$

21. Tamburino C, Capranzano P, Capodanno D et al. Percutaneous recanalization of chronic total occlusions: wherein lies the body of proof? Am Heart J, 2013; 165: 133-142.

22. Yamane M, Muto M, Matsubara T et al. Contemporary retrograde approach for the recanalisation of coronary chronic total occlusion: on behalf of the Japanese Retrograde Summit Group. EuroIntervention, 2013; 9: 102-109.

23. Tsuchikane E, Katoh O, Kimura $\mathrm{M}$ et al. The first clinical experience with a novel catheter for collateral channel tracking in retrograde approach for chronic coronary total occlusions. J Am Coll Cardiol Cardiovasc Interv, 2010; 3: 165-171.

24. Syrseloudis D, Secco GG, Barrero EA et al. Increase in J-CTO lesion complexity score explains the disparity between recanalisation success and evolution of chronic total occlusion strategies: insights from a single-centre 10-year experience. Heart, 2013; 99: 474-479. 


\title{
Udrożnienia przewlekłych okluzji tętnic wieńcowych metodą wsteczną: pierwsze polskie doświadczenia
}

\author{
Leszek Bryniarski ${ }^{1}$, Sławomir Surowiec ${ }^{1}$, Łukasz Klima ${ }^{1}$, Michał Terlecki ${ }^{1}$, Piotr Jankowski ${ }^{1}$, Marek Rajzer ${ }^{1}$, \\ Piotr Kusak ${ }^{1}$, Tadeusz Królikowski ${ }^{1}$, Adam Curyło ${ }^{1}$, Krzysztof Żmudka², Dariusz Dudek ${ }^{3}$, Danuta Czarnecka ${ }^{1}$ \\ II Klinika Kardiologii i Elektrokardiologii Interwencyjnej oraz Nadciśnienia Tętniczego, Szpital Uniwersytecki, Instytut Kardiologii, \\ Uniwersytet Jagielloński, Collegium Medicum, Kraków \\ ${ }^{2}$ Klinika Kardiologii Interwencyjnej, Szpital im. Jana Pawła II, Uniwersytet Jagielloński, Collegium Medicum, Kraków \\ 3॥ Klinika Kardiologii oraz Interwencji Sercowo-Naczyniowych, Szpital Uniwersytecki, Instytut Kardiologii, Uniwersytet Jagielloński, \\ Collegium Medicum, Kraków
}

\section{Streszczenie}

Wstęp: Skuteczność udrożnień przewlekłych okluzji tętnic wieńcowych ( CTO) zwiększyła się po wprowadzenie techniki udrożnienia z dostępu wstecznego (retrograde).

Cel: Celem niniejszej pracy było porównanie wyników udrożnień CTO w ośrodku w Krakowie z użyciem techniki klasycznej antegrade oraz retrograde.

Metody: Od stycznia 2011 do września 2013 r. w grupie 150 pacjentów wykonano 159 zabiegów udrożnień 153 przewlekle zamkniętych naczyń. Spośród 159 procedur 124 (78\%) wykonano z dostępu klasycznego, a 35 (22\%) z dostępu wstecznego. Wyniki: U wszystkich pacjentów występowały objawy, klasa CCS wynosiła średnio 2,3 $\pm 0,6$ vs. 2,1 $\pm 0,7$, odpowiednio $\mathrm{w}$ grupie retrograde $\mathrm{i}$ antegrade $(\mathrm{p}=0,9)$. Wiek w grupie retrograde wynosił średnio $59,2 \pm 8,3$ roku, a w grupie antegrade $-62,6 \pm 9,9(p=0,3)$. W obu grupach odsetek mężczyzn był podobny $(81,3 \%$ vs. 81,8\%; $p=0,9)$. Większość chorych miała zachowaną funkcję lewej komory ( $E F \geq 50 \% ; 84,4 \%$ vs. 74,4\%). Okluzje oceniono wg skali J-CTO, kwalifikując w grupie udrażnianej techniką wsteczną jako trudne lub bardzo trudne - 82,9\% przypadków, zaś w grupie antegrade - 56,4\% ( $<<0,01)$. Skuteczność zabiegu w całej grupie wyniosła 88,2\%. Skuteczność udrożnienia w grupie retrograde była równa $74,3 \%$, a w grupie antegrade - 87,9\%. Częstość komplikacji była niska i nie różniła się istotnie między grupami, jednak zastosowanie techniki wstecznej wiązało się z dłuższym czasem trwania zabiegu (97,0 0 20,2 vs. 57,3 \pm 19,9 min; p < 0,00001), fluoroskopii (47,8 \pm 19,6 vs. 19,3 \pm 10,0 min; $p<0,00001)$ i większą objętością podanego kontrastu $(494,6 \pm 142,4$ vs. $291,9 \pm 118,1 \mathrm{ml} ; \mathrm{p}<0,00001)$.

Wnioski: Stosując nowoczesny sprzęt i dysponując odpowiednim doświadczeniem, można uzyskać wysoki odsetek udrożnień CTO. Wprowadzenie udrożnień technniką wsteczną retrograde spowodowało poprawę skuteczności zabiegów i było bezpieczne.

Słowa kluczowe: przezskórne interwencje wieńcowe, przewlekłe okluzje tętnic wieńcowych, dostęp wsteczny

Kardiol Pol 2015; 73, 3: 167-176

\section{Adres do korespondencji:}

prof. dr hab. n. med. Leszek Bryniarski, I Klinika Kardiologii i Elektrokardiologii Interwencyjnej oraz Nadciśnienia Tętniczego, Szpital Uniwersytecki, Instytut Kardiologii, Uniwersytet Jagielloński, Collegium Medicum, ul. Kopernika 17, 31-501 Kraków, tel: +48 1242473 00, faks: +48 1242473 20, e-mail: I_bryniarski@poczta.fm Praca wpłynęła: 09.03.2014 r. Zaakceptowana do druku: 12.06.2014 r. Data publikacji AoP: 21.08.2014 r. 